\title{
Dobry Pasterz a pasterze Kościoła w Sermo 46 św. Augustyna
}

Pośród licznych dzieł św. Augustyna darmo szukać traktatu o kapłaństwie ${ }^{1}$ dorównującego rozmiarami i precyzją sformułowań jego pismom skierowanym przeciw manichejczykom czy pelagianom. Biskup Hippony mówił o posłudze duszpasterskiej przede wszystkim życiem, a największą siłą jego nauczania było osobiste świadectwo oddania Kościołowi. Wyświęcony na kapłana w 391 roku, a na biskupa - cztery lata później, przez blisko czterdzieści lat gorliwie głosił słowo Boże i sprawował sakramenty, służąc z miłością ludowi Bożemu. Świadomy rozdźwięku między własną słabością a wielkością powołania, grzesznością człowieka a godnością szafarza świętości, ograniczonymi możliwościami działania a wezwaniem do zadań uniwersalnych, pokornie zawierzał się Bogu, starając się łączyć modlitwę i czyn, słowo i praktykę życia. Sensem pasterzowania było dla Augustyna posługiwanie ludowi Bożemu: propter vos vivimus ${ }^{2}$. Tej misji poświęcił nawet wzniosłe pragnienie życia oddanego medytacji, studium Pisma Świętego i twór-

${ }^{1}$ Pogłębiona refleksja nad kapłaństwem, jego naturą, misją i zadaniami pojawiła się w Kościele dopiero w IV wieku po uzyskaniu przez chrześcijaństwo wolności kultu, a zatem po radykalnej zmianie jego statusu w Imperium Romanum i powiązaniu funkcji episkopalnej z działalnością sądową i administracyjną. Do najważniejszych dzieł o kapłaństwie w okresie patrystycznym należy zaliczyć: Efrem, Sermo de sacerdotio; Grzegorz z Nazjanzu, Oratio secunda; Jan Chryzostom, De sacerdotio; Ambroży, De officiis; Grzegorz Wielki, Regula pastoralis. Antologia tekstów patrystycznych z obszernym wstępem: M. Starowieyski, Kapłani i pasterze, Kraków 2010.

${ }^{2}$ Tractatus in Evangelium Ioannis, 18, 12. 
czości literackiej³. Duszpasterz „pokonał” teologa, którego geniusz musiał się podporządkować wymaganiom i dynamice życia kościelnej wspólnoty ${ }^{4}$. Widać to zwłaszcza w kazaniach, które przepojone słowem Bożym, nie są owocem suchych teorii ascetyczno-duchowych, ale stanowią odpowiedź na konkretne potrzeby ludzi. Augustyn ucieleśnia uniwersalną prawdę, iż każdy duszpasterz, wszczepiony i wpatrzony w jedynego Dobrego Pasterza, ma być wzorem dla wierzących, ma ich strzec i prowadzić, nauczać i uświęcać.

Takie jest zasadnicze przesłanie Kazania o pasterzach ${ }^{5}$ opartego na alegorycznej interpretacji Ez 34, 1-16, fragmentu, w którym prorok Ezechiel poddaje ostrej krytyce postawę pasterzy izraelskich i zapowiada objęcie pasterzowania nad ludem przez samego Pana. Obraz chrześcijańskiego kapłana nakreślony przez Augustyna 1600 lat temu w odmiennym kontekście kulturowym, eklezjalnym i geopolitycznym ${ }^{6}$ zdaje się nie tracić nic ze swojej aktualności. Biskup Hippony nie ogranicza sięjedynie do krytyki grzesznych i egoistycznych postaw, ale nade wszystko wskazuje istotę powołania kapłańskiego: całkowite oddanie Chrystusowi dla dobra ludu Bożego. Także i dziś Kościół zaprasza do medytacji Augustynowego Kazania o pasterzach poprzez zamieszczenie jego obszernych fragmentów w godzinie czytań 24 i 25 tygodnia zwykłego.

\section{Augustiański trójmian: fundament chrystologiczny, horyzont eschatologiczny, środowisko eklezjalne}

Wyjątkowa wartość kazań Augustyna tkwi niewątpliwie w ich inspiracji biblijnej i solidnych ramach teologiczno-filozoficznych. Choć wypowiedziane zostały do konkretnych ludzi, w określonym czasie, w odpowiedzi na pewne potrzeby, nie sąjedynie pouczeniami mającymi

${ }^{3}$ Augustyn po nawróceniu przez kilka lat żył wraz ze swymi przyjaciółmi na uboczu w swego rodzaju wspólnocie chrześcijańskiego życia najpierw w Cassiciacum, a potem w Tagaście. Monastyczny sposób życia zachował także w Hipponie już jako kapłan i biskup.

${ }^{4}$ Por. F. Van der Meer, S. Agostino pastore d'anime, Roma 1971, s. 12.

${ }^{5}$ Sermo 46. Opracowanie krytyczne tekstu łacińskiego, C. Lambot, Le sermon XLVI de saint Augustin „De pastoribus”, „Revue Bénédictine” 63 (1953), s. 165-210.

${ }^{6}$ Przyjmuje się, że Sermo 46 zostało wygłoszone pomiędzy 408 a 414 rokiem w Hipponie lub Kartaginie. Zabarwione jest, zwłaszcza w końcowej części, silną polemiką z donatystami. 
rozwiązać doraźne problemy, ale stanowią duchowy pokarm, z którego Kościół czerpie nieprzerwanie od szesnastu wieków. Biskup Hippony dociera do słuchacza takiego, jakim jest, by następnie prowadzić go cierpliwie w górę do źródła Boskiej tajemnicy. „Styl kazań jest kompromisem między prostotą a barokową obfitością, tak dobrze dostosowaną do afrykańskiej duszy, między potocznością a patetyzmem, między dialogiem z tłumem a słuchaniem słowa Bożego, jest bliższy Biblii niż sofistyce"?

Całe Kazanie o pasterzach Augustyn opiera na solidnym fundamencie chrystologicznym, podkreślając, iż jedynym Pasterzem Kościoła - teraz i w wieczności - jest Jezus Chrystus: „Nie po raz pierwszy dowiadujecie się, iż cała nasza nadzieja złożona jest w Chrystusie i że On sam jest naszą prawdziwą i zbawienną chwałą. Wszak jesteście w owczarni Tego, który strzeże i pasie Izraela"8. Fundament chrystologiczny jest dla Augustyna podstawową rzeczywistością warunkującą rozumienie Kościoła oraz wszelkich podejmowanych w nim posług i sprawowanych urzędów. Zdaniem biskupa Hippony w obrazie pasterz-owce pierwszy element w ścisłym znaczeniu tego słowa odnosi się jedynie do Jezusa Chrystusa, natomiast drugi symbolizuje wszystkich wierzących. Istnienie hierarchii w Kościele nie może przesłonić podstawowej równości chrześcijan i ich jednakowej godności. Wobec Chrystusa każdy jest podmiotem odpowiedzialnym za własne zbawienie, choć niektórym została powierzona specjalna troska również o zbawienie innych: ,Jako chrześcijanie mamy zabiegać o własne zbawienie, jako pasterze powinniśmy troszczyć się wyłącznie o wasze dobro. Wielu jest chrześcijan, którzy nie są pasterzami. Zmierzają do Boga łatwiejszą - jak się zdaje - drogą i tym prędzej, im mniejszy dźwigają ciężar. My zaś, jako chrześcijanie, mamy zdać Bogu rachunek z własnego życia; ale ponadto jesteśmy pasterzami i dlatego będziemy składać rachunek również z naszego pasterzowania".

Augustyn od początku swej drogi pasterskiej, do podjęcia której został notabene w pewien sposób przymuszony przez chrześcijan z Hip-

${ }^{7}$ A. Hamman, Życie codzienne w Afryce Pótnocnej w czasach św. Augustyna, Warszawa 1989, s. 239.

${ }^{8}$ Sermo 46, 1, 2-4, [w:] Liturgia godzin. Codzienna modlitwa ludu Bożego, t. 4: Okres zwykły. Tygodnie XVIII-XXXIV, Poznań 1988, s. 190.

${ }^{9}$ Sermo 46, 2, 23-29, [w:] Liturgia godzin..., dz. cyt., t. 4, s. 191. 
pony ${ }^{10}$, czuł ciężar odpowiedzialności spoczywający na jego barkach. Wynikał on ze świadomości godności piastowanego urzędu, ogromu i różnorodności potrzeb powierzonych mu ludzi, konieczności zdania sprawy przed Bogiem ze swojego włodarzowania. Spojrzenie Augustyna nie ogranicza się do doraźnych zadań, ale sięga horyzontu wieczności. Jako biskup ma jasną świadomość, że jego posługa to walka o zbawienie ludzi. A zatem należy głosić prawdę „w porę i nie w porę” (2 Tm 4, 2), by ich jak najlepiej przygotować na nadchodzące spotkanie z Bogiem: „Nadejdzie bowiem dzień, kiedy wszystko zostanie poddane pod sąd. A dzień ten, nawet jeśli dla świata jest odległy, to dla poszczególnych ludzi jest bliski jako ostatni dzień życia"11.

Jasna świadomość eschatologicznej perspektywy rzutuje w sposób zasadniczy na sposób widzenia teraźniejszości. Augustyn podkreśla konieczność zabiegania o własne zbawienie „z bojaźnią i drżeniem” (Flp 2, 12) i wystrzegania się zuchwałej ufności w miłosierdzie Boże. Zdecydowanie przeciwstawia się kaznodziejom, którzy usypiają czujność wierzących, nie krytykują grzechów i błędnych zachowań ludzi, a przywołując jedynie zbawczą wolę Boga, przyczyniają się do rozluźnienia ich postaw moralnych: „Obyśmy nigdy wam nie głosili: żyjcie, jak wam się podoba! Bądźcie spokojni, Bóg nikogo nie potępi! Wystarczy, że zachowacie chrześcijańską wiarę. Nie potępi tego, kogo odkupił i za kogo przelał krew! [...] Wielkie jest przecież miłosierdzie Boże, które wszystko przebacza. Uwijcie sobie wieniec z róż, zanim zwiędną. [...] Jeśli tak byśmy czynili, głosilibyśmy nie słowa Boże i Chrystusowe, ale własne: bylibyśmy pasterzami pasącymi samych siebie, a nie owce"12.

Podstawowym zadaniem pasterza jest głoszenie prawdy o Bogu-Jego miłości i przykazaniach, o człowieku - jego powołaniu i zadaniach i o Kościele jako przestrzeni zbawczej, w której Chrystus pragnie zjednoczyć wszystkich ludzi. Właściwe środowisko eklezjalne to - obok fundamentu chrystologicznego i horyzontu eschatologicznego - trzeci element augustiańskiego trójmianu nakreślonego w Kazaniu o pasterzach. Biskup Hippony akcentuje, że katolickość, czyli powszechność, to zasadniczy wyznacznik prawdziwości Kościoła. Dlatego w ostrym tonie krytykuje

${ }^{10}$ Por. Possydiusz, Vita sancti Augustini, IV, 2.

${ }^{11}$ Por. Sermo 46, 2, 31-33 (tłum. własne).

${ }^{12}$ Sermo 46, 8, 135-137. 141-142. 148-149 (tłum. własne). 
różne herezje i schizmy, uważając je za pochodzące od diabła ${ }^{13}$. Heretycy to wilki w owczej skórze ${ }^{14}$ - nie głoszą prawdy Bożej, ale własne nauki, powołując sięraczej na dokumenty ludzkie niż Pismo Święte, które na dodatek pokrętnie interpretują ${ }^{15}$.W sposób szczególny Augustyn podejmuje polemikę z donatystami, którzy pretendowali do uosabiania prawdziwego Kościoła świętych, jedynego spadkobiercy tradycji Cyprianowej. Podkreśla, że Kościół katolicki jest obecny w całym świecie i nie może ograniczać się jedynie do małego terytorium północnoafrykańskiego. Donatyści odłączyli się od jedności Kościoła, a zatem są poza owczarnią Chrystusową. Augustyn zwraca uwagę na fakt, że to Piotrowi powierzone zostało zadanie pasienia owiec. Odczytując Pnp 1, 7 w świetle J 21, 17 i Mt 25, 33, przyrównuje on donatystów do kozłów, których czeka marny los: „Czyż nie wiecie, bracia, gdzie znajdą się kozły? Wszyscy, którzy wychodzą z Kościoła, skończą po lewej stronie"16.

Wyraźne odróżnienie Kościoła od grup heretyckich i schizmatyckich nie przeszkadza Augustynowi w zachowaniu postawy otwartości. Jest gotowy przyjąć donatystów do wspólnoty, a nawet poszukuje jedności z nimi. W przeciwieństwie do swoich adwersarzy, którzy ponownie chrzcili przystających do nich chrześcijan, biskup Hippony uznaje ważność sakramentów udzielanych przez schizmatyków, którzy choć są źli, to jednak pozostają braćmi ${ }^{17}$. Ich błądzenie nie jest jednak obojętne. Jako dobry pasterz czuje się przymuszony do poszukiwania owiec, które się zagubiły: „Kiedy poszukujemy zabłąkanych, twierdzą w swym błędzie i zagubieniu, że nie należą do nas: «Czego chcecie od nas? Dlaczego nas szukacie?» Jak gdyby to, że błąkają się i giną, nie było wystarczającym powodem, abyśmy wołali i poszukiwali. «Jeśli zbłądziłem - powiada - jeśli zagubiłem się, czego chcesz ode mnie? Czemu mnie szukasz?» Otóż ponieważ trwasz w błędzie, chcę cię sprowadzić z powrotem, ponieważ zagubiłeś się, chcę cię odnaleźć. «A właśnie ja chcę błądzić, ja chcę ginąć». Ty chcesz

${ }^{13}$ Por. Sermo 46, 28.

${ }^{14}$ Por. Sermo 46, 31.

${ }^{15}$ Por. Sermo 46, 33.

${ }^{16}$ Sermo 46, 37, 873-874 (tłum. własne).

${ }_{17}$ Por. Sermo 46, 31, 703-704. Polemika z donatystami doprowadziła Augustyna do wyraźnego odróżnienia działania Chrystusa przez słowo i sakramenty od roli szafarza. „Wierzący nie rodzi się z bezpłodności szafarza, lecz z płodności Prawdy” - Contra litteras Petiliani donatistae libri tres, II, 5, 11 (tłum. własne). 
błądzić, chcesz ginąć? Otóż ja jeszcze bardziej nie chcę. Powiem jasno, jestem natrętny [...]. Chcesz czy nie chcesz, będę tak czynił. Przebiegnę każdą ścieżynę, nawet jeśli podczas szukania ranić mnie będą krzewy leśne. [...] Jeśli nie chcesz, abym cierpiał, nie chciej się gubić"18. Zacytowany fragment, który doskonale streszcza w sobie augustiański trójmian, jest równocześnie klarownym przykładem oratorskiej sztuki jednego z najwybitniejszych kaznodziejów w dziejach Kościoła. Jego język jest żywy, obrazowy, dostosowany do poziomu słuchaczy, treść uwarunkowana potrzebami wspólnoty, a jednocześnie przeniknięta odniesieniami biblijnymi. Tak sugestywnym językiem Augustyn kreśli przed wiernymi wyrazisty obraz dobrego pasterza, który troszczy się o swoje owce. Wcześniej jednak zgodnie z dynamiką proroctwa Ez 34, 1-16 poddaje ostrej krytyce zaniedbania i niewłaściwe postawy kapłańskie, zwłaszcza egoizm i oglądanie się na własne korzyści.

\section{Pastores se ipsos pascentes}

Misja kapłańska to służba ludowi Bożemu. Tak postrzega ją biskup Hippony. Nic zatem dziwnego, że najbardziej ostre słowa kieruje przeciw tym, którzy wypaczają samą istotę duszpasterzowania. Jego krytyka jest zdecydowana i jasna co do treści, natomiast sposób jej wyrażania odsłania mistrza słowa, a przy tym człowieka zatroskanego o dobro Kościoła. Punktem wyjścia nie jest wbrew pozorom niepokojąca rzeczywistość duszpasterska, ale słowo Boże, w którego świetle ta rzeczywistość zostaje oceniona. Kazanie jest ujęte w formę alegorycznej interpretacji będącej aktualizującą egzegezą poszczególnych wyrażeń Ezechielowego proroctwa. Dzięki takiemu zabiegowi obrazom zaczerpniętym z życia pasterskiego zostaje przypisane nowe znaczenie. A zatem czego pragną, a co - zdaniem Augustyna - zaniedbują źli pasterze?

„Nakarmiliście się mlekiem, odzialiście się wełną” (Ez 34, 3)

Cytując to wyrażenie, biskup Hippony nie sili się na subtelności egzegetyczne, ale stwierdza jednoznacznie: „Dawać mleko to tyle, co dawać utrzymanie, dostarczać zaś wełny oznacza okazywać szacunek. Ci, którzy

${ }^{18}$ Sermo 46, 14, 296-303. 312-313. 315, [w:] Liturgia godzin..., dz. cyt., t. 4, s. 221. 
siebie samych pasą, a nie owce, wymagają tych dwóch rzeczy od ludu: aby zaradzał ich potrzebom i aby okazywał im szacunek i uznanie"1

Hierarchia kościelna w V wieku zdaje się ulegać groźnej pokusie hołdowania wartościom doczesnym. Pragnienie pieniędzy i zaszczytów uderza bowiem w samą istotę posługi duszpasterskiej. Kapłan czy biskup zapatrzony egoistycznie we własne potrzeby i szukający jedynie własnych korzyści staje się w końcu ich niewolnikiem i sprzeniewierza służebnej misji powierzonej mu przez Chrystusa. Zdecydowana krytyka takich postaw nie przekreśla trzeźwego realizmu Augustyna. Zdaje on sobie sprawę, że nawet w Kościele nie sposób uciec od ekonomii. Jak zatem pogodzić darmowość zbawienia z materialnymi potrzebami życia kościelnego? Augustyn rozwiązuje dylemat w typowy dla siebie sposób, to znaczy przez odwołanie się do innych tekstów Pisma Świętego, które mają rozjaśnić rozważaną kwestię. W tym przypadku z pomocą przychodzi św. Paweł. Kaznodzieja zauważa, że wprawdzie Apostoł potwierdził prawo głosicieli słowa Bożego do utrzymania, ale sam poszedł o krok dalej, zarabiając na życie pracą własnych rąk. „Cóż więcej należałoby powiedzieć o tych, którzy zrzekają się mleka trzody? Są bardziej miłosierni albo raczej wspaniałomyślniej sprawują dzieło miłosierdzia. Tak właśnie potrafią, a co potrafią, to czynią. Tacy godni są pochwały, ale tamci nie zasługują na naganę"20.

Augustyn podkreśla, że składanie ofiar przez wiernych wypływa nie tylko z konieczności, ale ma również głębszy wymiar:jest konkretnym wyrazem ich duchowej płodności. W ten właśnie sposób interpretuje epizod przyjęcia przez św. Pawła materialnej pomocy od Filipian podczas pobytu w rzymskim więzieniu (por. Flp 4, 10-14). „[Paweł] nie tyle się cieszy okazaną mu pomocą, ile raczej wyraża radość z powodu ich wielkoduszności. Czegóż więc szukał w ich czynie? „Nie pragnę - rzecze - waszego daru, ale owocu" (Flp 4, 17). Nie żebym sam miał obfitować, ale abyście wy nie byli pozbawieni owocu"21.

Chodzi zatem o sferę motywacji i właściwe określenie celu. Różnica między postawą merkantylną a wielkodusznością duszpasterską dokonuje się w sercu. Ofiary materialne są wprawdzie konieczne, ale ich

\footnotetext{
${ }^{19}$ Sermo 46, 6, 106-109, [w:] Liturgia godzin..., dz. cyt., t. 4, s. 201.

${ }^{20}$ Sermo 46, 4, 67-70, [w:] Liturgia godzin..., dz. cyt., t. 4, s. 195.

${ }^{21}$ Sermo 46, 4, 79-82, [w:] Liturgia godzin..., dz. cyt., t. 4, s. 198.
} 
składanie, jak i przyjmowanie powinny służyć jedynie pomnażaniu dobra Kościoła. „Nie jakoby Ewangelia była na sprzedaż i kosztowała tyle, ile wyżywienie jej głosicieli. Jeśliby się ją tak sprzedawało, dawałoby się za niską cenę rzecz prawdziwie wielką. Niech już raczej jej głosiciele otrzymują od ludu konieczne utrzymanie, natomiast zapłatę posługiwania od Pana"22. Słowo Boże nie jest na sprzedaż, a głoszenie go jest rzeczywistością bezcenną. Jedynie Chrystus jest w stanie sprawiedliwie wynagrodzić pełną miłości służbę ewangelizatorów. I jedynie takiej zapłaty powinni oni szukać, nie oglądając się na doczesne korzyści i nie uzależniając od nich pełnienia wzniosłej misji. Napiętnowani są zatem tylko ci pasterze, którzy „pijąc mleko i odziewając się wełną, zaniedbują owce. Szukają jedynie własnej korzyści, a nie Jezusa Chrystusa"23.

Augustyn wykazuje duże zrozumienie także dla naturalnej potrzeby uznania symbolizowanej przez wełnę. Szacunek okrywa nagość człowieka, to znaczy ludzką ograniczoność, nędzę i śmiertelność. Problem pojawia się w momencie, gdy z obawy przed jego utratą duszpasterz przestaje głosić trudne i wymagające prawdy Boże. Właściwym kryterium oceny ewangelizatora nie jest popularność, ale wierność słowu Bożemu. Przykładem takiej postawy jest znów św. Paweł, który z jednej strony cieszy się, że jest przyjmowany przez Galatów jak „anioł Boży” (Ga 4,14), a z drugiej nie obawia się skrytykować ich niewłaściwych postaw i zachowań. Gdyby postąpił inaczej, byłby „pasterzem pasącym samego siebie”. „Powiedziałby wtedy do siebie: co mnie to obchodzi? Niech każdy czyni, co chce: mam utrzymanie, mam szacunek; mleka i wełny mi wystarczy; niech każdy idzie, dokąd może"24.

Augustyn podkreśla z naciskiem, że Apostoł nigdy nie zaniedbywał Chrystusowych owiec, nawet jeśli korzystał z ich mleka i wełny. Przeciwnie, dbał o nie nieustannie, głosząc Ewangelię w porę i nie w porę. Prawda Boża jest bowiem jedynym lekarstwem na choroby duszy, a dobry pasterz „pochyla się nad owcą słabą i chorą, aby naciąć ranę, i nie pobłaża chorobie"25. Biskup Hippony zdaje sobie sprawę, że newralgicznym punktem duszpasterskim jest głoszenie prawd niepopular-

\footnotetext{
${ }^{22}$ Sermo 46, 5, 96-99, [w:] Liturgia godzin..., dz. cyt., t. 4, s. 199.

${ }^{23}$ Sermo 46, 5, 102-104, [w:] Liturgia godzin..., dz. cyt., t. 4, s. 199.

${ }^{24}$ Sermo 46, 7, 121-123, [w:] Liturgia godzin..., dz. cyt., t. 4, s. 202.

${ }^{25}$ Sermo 46, 7, 130-131, [w:] Liturgia godzin..., dz. cyt., t. 4, s. 202.
} 
nych, trudnych, wymagających, takich, które napotykają opór, a nawet sprzeciw słuchaczy. Odrzuca jednak pokusę taniego populizmu. Kapłan ma głosić słowo Boże, a nie własne. Prawda jest ważniejsza od osobistej popularności i zadowolenia odbiorców!

„Zabiliście tłuste owce, jednakże owiec nie paśliście.

Słabej nie wzmacnialiście, o zdrowie chorej nie dbaliście,

skaleczonej nie opatrywaliście, zabłąkanej nie sprowadziliście

z powrotem, zagubionej nie odszukiwaliście" (Ez 34, 3-4)

Augustyn nie ogranicza się do krytyki niewłaściwych pragnień i aspiracji złych pasterzy, ale wytyka również ich zaniedbania. Godne potępienia jest zwłaszcza gorszące postępowanie. „Próżnym głosicielem słowa Bożego na zewnątrz jest ten, kto wewnątrz nie jest jego słuchaczem"26. Antyprzykład zabija dobre obyczaje. Brak ewangelicznego świadectwa duszpasterza zagraża wszystkim, nie tylko chwiejącym się czy wątpiącym, ale nawet tym nielicznym, którzy są mocni we wierze. „Oto nawet zdrowa owca, patrząc na swego źle postępującego pasterza, odwraca oczy od przykazań Pańskich, kieruje je ku człowiekowi i zaczyna mówić w sercu swoim: «Jeśli mój pasterz tak postępuje, kimże ja jestem, aby nie czynić tak samo?» W ten sposób zły pasterz zabija zdrową owcę. Jeśli zdrową zabija, to cóż uczyni z innymi?"27.

Augustyn podkreśla z naciskiem, że zły przykład, nawet jeśli nie prowadzi do rzeczywistej śmierci duchowej, jest zabójstwem, podobnie jak pożądliwość zrodzona w sercu jest cudzołóstwem (por. Mt 5, 28). Trwanie chrześcijan w wierze pomimo złego życia duszpasterzy jest skutkiem Bożego miłosierdzia, owocem ich posłuszeństwa słowu Bożemu i zachowywania przykazań. W tym cudzie łaski unaocznia się bardzo wyraźnie pierwszy element augustiańskiego trójmianu, tj. fundament chrystologiczny: „Nie pasterze was pasą, lecz Bóg, ponieważ chcąc nie chcąc muszą głosić słowo Boże, aby otrzymać mleko i wełnę"28.

Brak dobrego przykładu ze strony ziemskich pasterzy nie zwalnia chrześcijan od osobistej odpowiedzialności za życie i postępowanie. Nawet w ustach niegodziwców słowo Boże jest prawdą. „Czyńcie więc i za-

\footnotetext{
${ }^{26}$ Sermo 179, 1 (tłum. własne).

${ }^{27}$ Sermo 46, 9, 160-165, [w:] Liturgia godzin..., dz. cyt., t. 4, s. 205.

${ }^{28}$ Sermo 46, 22, 491-492 (tłum. własne).
} 
chowujcie wszystko, co wam polecą, lecz uczynków ich nie naśladujcie" (Mt 23, 3). Ten cytat zdaniem Augustyna jest wyjaśnieniem proroctwa Ez 34, 10 mówiącego o wyrwaniu owiec z rąk złych pasterzy. Chrześcijanie posłuszni słowu Bożemu, a nie naśladujący grzechów złych duszpasterzy okazują, że sam Bóg jest ich Pasterzem. Ziemski głosiciel jest narzędziem, ważnym i pomocnym, ale chrześcijanie mają bezpośredni dostęp do Chrystusa i są moralnie zobowiązani do szukania prawdy i duchowego rozeznawania. „Człowiek bezbożny umrze i umrze zasłużenie. Umrze w swej bezbożności i w swoim grzechu. Jego własna niedbałość go zabiła. Bo mógłby znaleźć żyjącego Pasterza, który mówi: «Żyję Ja - mówi - Pan». Ponieważ jednak był niedbały i ponieważ ten, który został ustanowiony stróżem i przewodnikiem, aby napominać, nie upominał, dlatego słusznie umrze ten, ale i tamten zostanie odrzucony"29.

Podstawowym obowiązkiem duszpasterza jest żyć prawdą i gorliwie ją głosić. Szczególnie ważne jest reagowanie na zagrożenia i pomaganie wierzącym w ich przezwyciężaniu. Dla Augustyna takimi wciąż czyhającymi niebezpieczeństwami są herezje i schizmy. Podkreśla on, że brak reakcji - chociażby słownej - na przyłączanie się katolików do donatystów stanowi bierne przyzwolenie na porzucanie Kościoła także przez innych jego członków, a więc jest zabijaniem owiec ${ }^{30}$. Duszpasterz nie może ani dopuszczać, ani przez swoje zaniedbania doprowadzać do odchodzenia owiec z Chrystusowej owczarni, czyli do odłączania się od katolickiego środowiska eklezjalnego. Tylko ono jest życiodajne, natomiast grupy heretyckie czy schizmatyckie można porównać do winnych latorośli odciętych od winnego $\mathrm{krzewu}^{31}$.

Biskup Hippony wie z doświadczenia, że decyzja o porzuceniu Kościoła nie następuje zazwyczaj w jednej chwili, ale jest długotrwałym i narastającym procesem. Stosownie do Ezechielowego proroctwa wskazuje on, że najpierw następuje osłabienie, potem choroba, a wreszcie zabłąkanie. „Między tymi, które są słabe, czyli wątłe (bo także chore nazywa się słabymi), a zatem pomiędzy owcą słabą a chorą, to jest taką, której coś dolega, istnieje następująca - jak sądzę - różnica. [...] W wypadku człowieka słabego lękać się trzeba, aby nie spotkała go pokusa i nie załamała. Kto zaś

\footnotetext{
${ }^{29}$ Sermo 46, 20, 440-444, [w:] Liturgia godzin..., dz. cyt., t. 4, s. 228.

${ }^{30}$ Por. Sermo 46, 15. 21

${ }^{31}$ Por. Sermo 46, 18 (fragment oparty na egzegezie J 15, 1-6).
} 
jest chory, już niedomaga z powodu jakiejś pożądliwości powstrzymującej przed wkroczeniem na Bożą drogę i oddaniem się na służbę Chrystusa"32.

Dobry duszpasterz nie powinien reagować dopiero w obliczu śmierci (duchowej czy eklezjalnej), ale przychodzić z pomocą, gdy zauważy już pierwsze oznaki słabości. Jego zadaniem jest wzmacnianie słabej owcy, której serce jest „,kłonne ulec w obliczu pokus, jeśli spotka się z nimi nie przestrzeżona i nie przygotowana" ${ }^{33}$. Jakie pokusy ma na myśli Augustyn? Jako znawca meandrów życia wskazuje przede wszystkim na załamanie w obliczu cierpień i przeciwności losu. Nieszczęścia, które spadają na człowieka, mogą bowiem doprowadzić do załamania się wiary w opatrzność Bożą. Dlatego Augustyn apeluje do kaznodziejów, by budowali na skale, tj. na Chrystusie, a nie na piasku (por. Mt 7, 24; 1 Kor 10, 4). Oznacza to wdrażanie chrześcijanina do naśladowania Mistrza, w sposób szczególny Jego cierpień, a niełudzenie mirażami spokojnego, bezpiecznego i przyjemnego życia w świecie. „Jeśli bowiem przyzwyczai się pokładać ufność w pomyślności ziemskiej, przywiedzie go ona do upadku, gdy zaś spotkają go przeciwności, będzie cierpiał, albo nawet zupełnie zginie" ${ }^{34}$.

Augustyn podkreśla z naciskiem, że chrześcijanin niewątpliwie napotka przeciwności i będzie poddany cierpieniom właśnie dlatego, że jest chrześcijaninem. Głoszenie takiej prawdy jest z pewnością niepopularne, ale za to przygotowuje wierzącego na czas próby i w konsekwencji umacnia jego wiarę. Nie chodzi o defetyzm, ale o realizm. Prawdziwa nadzieja pochodzi od Boga, który dopuszcza bolesne doświadczenia, ale też udziela sił do pokonania wszelkich trudności. „Aby człowiek słaby $^{35}$ nie załamał się w obliczu przyszłych doświadczeń, nie wolno oczywiście łudzić fałszywą nadzieją ani napawać lękiem. Takiemu trzeba powiedzieć: „Przygotuj swą duszę na doświadczenia” (Syr 2, 1). Wtedy, być może, zacznie się chwiać, lękać, wycofywać. Wówczas powiedz: „Wierny jest Bóg i nie dozwala was doświadczać ponad to, co potraficie znieść" (1 Kor 10,13). Tak obiecać i zapowiedzieć mające nadejść cierpienie - oto na czym polega wzmocnienie słabego. Kiedy zaś ktoś

\footnotetext{
${ }^{32}$ Sermo 46, 13, 259-262. 265-268, [w:] Liturgia godzin..., dz. cyt., t. 4, s. 216-217.

${ }^{33}$ Por. Sermo 46, 10, 186-187, [w:] Liturgia godzin..., dz. cyt., t. 4, s. 208.

${ }^{34}$ Sermo 46, 10, 191-193, [w:] Liturgia godzin..., dz. cyt., t. 4, s. 208.

${ }^{35}$ W tłumaczeniu Liturgii godzin użyto słowa „chory”, jednak z całego kontekstu wynika, że słowo infirmus należy tu oddać jako „słaby”.
} 
przerazi się i zalęknie, obiecaj miłosierdzie Boże. Nie jakoby nie miało już być doświadczeń, ale że Bóg nie dozwoli doświadczać go ponad to, co potrafi znieść. Na tym właśnie polega założenie opatrunku" ${ }^{36}$.

Wobec zapowiedzi przyszłego cierpienia reakcje mogą być różne. Niektórzy, wyzbywszy się iluzji, wychodzą mu naprzeciw z podniesionym czołem i wręcz dążą do chwały męczeństwa. Słabi mają chwile załamań i zwątpień. Tym ostatnim nie wystarczy głosić prawdy, ale należy podać jeszcze opatrunek pocieszenia i zawiązać ranę, to znaczy zapewnić o bliskości Chrystusa w każdym doświadczeniu.

W odróżnieniu od „słabych”, którzy wprawdzie starają się czynić dobro, ale nie potrafią znosić zła, „chorzy” to ludzie, którzy „miłując świat, na skutek jakiejś pożądliwości są odrywani od czynów dobrych"37. Augustyn przyrównuje ich do paralityka, który nie może się poruszać o własnych siłach (por. Mk 2, 1-11). Ten wewnętrzny paraliż wymaga interwencji lekarza, który „być może jest ukryty i znajduje się wewnątrz: jest nim prawdziwe znaczenie ukryte w Piśmie" ${ }^{38}$. Z takiej interpretacji wynika kolejne zadanie duszpasterza: ma pomagać chrześcijaninowi zagłębiać się w nauce Ewangelii i wypływać na duchową głębię. Kapłan jest powołany do formacji ludu Bożego, karmienia jego i siebie chlebem słowa ${ }^{39}$. Sam Augustyn czyni to w sposób mistrzowski, oferując pożywny pokarm zdolny zadowolić najbardziej wymagające gusta i zaspokoić głód wszystkich, zarówno małych, jak i wielkich ${ }^{40}$.

Ostatnim zaniedbaniem duszpasterzy napiętnowanym przez biskupa Hippony jest nieszukanie owiec zabłąkanych i zagubionych. Polemiczny kontekst kazania jest aż nadto wyraźny. Siła grup heretyckich i schizmatyckich jest tak ogromna, że katolicy przypominają owce poruszające się wśród „zbójców” i narażone „na kły rozszalałych wilków” ${ }^{11}$. Wobec tego śmiertelnego niebezpieczeństwa ton przemowy Augustyna staje się szczególnie dosadny. Duszpasterz ma niestrudzenie poszukiwać

${ }^{36}$ Sermo 46, 12, 232-240, [w:] Liturgia godzin..., dz. cyt., t. 4, s. 213.

${ }^{37}$ Sermo 46, 13, 273-274, [w:] Liturgia godzin..., dz. cyt., t. 4, s. 217.

${ }^{38}$ Sermo 46, 13, 283-284, [w:] Liturgia godzin..., dz. cyt., t. 4, s. 217.

${ }^{39}$ Por. Sermo 95, 1; 229/E, 4.

${ }^{40}$ Por. G. Ceriotti, Introduzione, [w:] Sul sacerdozio (pagine scelte dai Discorsi di Sant'Agostino), Roma 1993, s. 40.

${ }^{41}$ Por. Sermo 46, 14. 
zagubionej owcy i starać się przyprowadzić ją z powrotem do owczarni Kościoła, nawet gdyby ona sama się opierała. To jego obowiązek, z którego wypełniania będzie musiał zdać sprawę przed trybunałem Chrystusa ${ }^{42}$. Podstawową misją kapłana jest bowiem gromadzenie ludzi w jednej wierze i we wspólnocie Kościoła powszechnego ${ }^{43}$. „Ta zatem matka, Kościół katolicki i jego Pasterz, szuka wszędzie zbłąkanych, umacnia słabych, leczy chorych, opatruje złamanych, troszczy się o tych i o tamtych. [Heretycy] nie znają się między sobą, ale Kościół zna wszystkich, bo jest ze wszystkimi" ${ }^{44}$.

\section{Pastores boni}

Obraz Kościoła w Afryce Północnej wyłaniający się z Kazania o pasterzach nie jest świetlany: panoszące się liczne herezje i błędy doktrynalne, schizma donatystów rozdzierająca jedność, a ponadto niewłaściwe postawy kapłanów i biskupów pogłębiające problemy i skutkujące poważnymi zaniedbaniami duszpasterskimi. Nie dziwi zatem, że Augustyn zastanawia się nawet, czy w ogóle istnieją dobrzy pasterze $^{45}$. Wątpliwość jest tym bardziej uprawniona, że proroctwo Ezechiela zapowiada, iż Bóg wyrwie owce z rąk złych pasterzy i sam będzie sprawował nad nimi pieczę (por. Ez 34, 10-16). Biskup Hippony szuka rozwiązania tego dylematu w sprawdzony już sposób, to znaczy w innych passusach Pisma Świętego, zwłaszcza w Nowym Testamencie. „Komu powierza [Bóg] owce, które odebrał tamtym [złym pasterzom]? Czy dobrym pasterzom? Dalej [w proroctwie Ezechiela] nie ma o tym mowy. Cóż więc powiemy, bracia? Czyżby nie było dobrych pasterzy? Czy nie powiedziano jednak w innym miejscu Pisma: „I dam im pasterzy według serca mego, i będą ich paśli rozsądnie” (Jr 3, 15)? W jakim więc sensie [Bóg] nie oddaje dobrym owiec, które odbiera złym paste-

${ }^{42}$ Jeżeli biskup katolicki, który nie poszukiwał zagubionych członków Kościoła, poniesie surową karę za swe zaniedbania, to jak wielka wina i odpowiedzialność spoczywa na przełożonych heretyków, którzy do błędu zachęcają i w nim utwierdzają? - zapytuje Augustyn; por. Sermo 46, 21, 485-488.

${ }^{43}$ W celu przywrócenia jedności kościelnej w poszczególnych miastach, Augustyn proponował nawet, aby biskupi (katolik i donatysta) złożyli dymisje z urzędu, pozwalając wybrać jednego biskupa dla wszystkich chrześcijan - por. Ep. 128, 3.

${ }^{44}$ Sermo 46, 18, 391-394, [w:] Liturgia godzin..., dz. cyt., t. 4, s. 224-225.

${ }^{45}$ Por. Sermo 46, 28, 602: „Dobrych pasterzy albo nie ma, albo są ukryci” (tłum. własne). 
rzom, ale jakoby nigdzie nie pozostali dobrzy, mówi: „Ja sam będę pasł” (Ez 34, 15)? Do Piotra jednak powiedział: „Paś owce moje” (J 21, 15). Jak rozwiążemy ten dylemat?"46.

Przez tak wyraźne postawienie problemu, który zdaje się wynikać nie tylko z bieżącej trudnej sytuacji eklezjalnej, ale z samej Biblii, Augustyn zmusza słuchaczy do refleksji i wytężenia uwagi. Dzięki temu otwiera ich na przyjęcie odpowiedzi ukazującej najgłębszą tajemnicę kapłaństwa. Najwyższy Pasterz pasie swoje owce $w$ i poprzez wybranych ludzi. Pasterze Kościoła są wtedy dobrzy, kiedy są wszczepieni w Jedynego Pasterza, trwają w Nim i pełnią Jego misję. ,W jednym Pasterzu odnajduję tu wszystkich dobrych pasterzy. Nie brak bowiem dobrych pasterzy, ale wszyscy są w Jednym. Wielu jest wówczas, gdy są podzieleni. Tutaj wymieniony jest Jeden dla podkreślenia jedności. Nie jest również prawdą, iż dlatego nie wspomina się o pasterzach, ale o Pasterzu, ponieważ Pan nie znajduje nikogo, komu mógłby powierzyć owce. Niegdyś powierzył, bo znalazł Piotra. Wszakże i w osobie Piotra zalecił jedność. Wielu było Apostołów, ale jednemu powiedziano: „Paś owce moje” (J 21, 15). Nie brak dobrych pasterzy, bynajmniej nie brakuje ich nam; miłosierdzie Boże wzbudza ich i stawia na czele Kościoła. Niewątpliwie, jeśli owce są dobre, dobrzy są także i pasterze, ponieważ dobrzy pasterze wywodzą się z dobrych owiec. Wszyscy jednak dobrzy pasterze są w Jednym i jedno stanowią, gdy oni pasą, Chrystus pasie. Przyjaciele oblubieńca nie przemawiają własnym głosem, ale radują się na głos oblubieńca. Dlatego gdy oni pasą, Chrystus pasie i mówi: «To Ja pasę». W nich bowiem jest Jego głos i Jego miłość. Także i Piotra, któremu powierzył owce jak drugiemu sobie, zjednoczył z sobą; w ten sposób powierzył mu owce, by on sam pozostał Głową, Piotr zaś obrazem Ciała, to jest Kościoła, i by byli jak oblubieniec i oblubienica dwoje w jednym ciele" 47 .

Wspaniała teologia kapłaństwa przedstawiona przez Augustyna ${ }^{48}$ jest aż nadto klarowna. Przewodniczenie wspólnocie nie jest funkcją hierarchiczną wynikającą z konieczności organizacyjnych i porządkowych w Kościele. Kapłan zostaje wszczepiony w Chrystusa celem pełnienia określonej misji. „W ten sposób pasie Chrystus, w ten sposób

\footnotetext{
${ }^{46}$ Sermo 46, 23, 516-523 (tłum. własne).

${ }^{47}$ Sermo 46, 30, 649-665, [w:] Liturgia godzin..., dz. cyt., t. 4, s. 234-235.

${ }^{48}$ Por. J. Pintard, Le sacerdoce selon Saint Augustin, Tours 1960.
} 
pasie się dla Chrystusa i w Chrystusie, nie zaś dla siebie samego z dala od Chrystusa" ${ }^{49}$. Ponieważ jedyny Pasterz jest Głową Ciała, czyli Kościoła, a zatem misja kapłańska polega na jednoczeniu wszystkich w jednym organizmie eklezjalnym. Augustyn podkreśla ponadto, że widzialnym znakiem jedności został ustanowiony apostoł Piotr, którego Zmartwychwstały doprowadził do trzykrotnego wyznania miłości. Chrystus „umacnia miłość, aby zapewnić jedność. Tak więc On sam pasie w nich, oni zaś pasą w Nim jednym"50.

Wersetem biblijnym, który odgrywa zasadniczą rolę w rozwiązaniu dylematu postawionego przez Augustyna jest J 10, 27: „Moje owce słuchają mego głosu [...]. Idą one za Mną"51. Kluczowe znaczenie tego wersetu wynika z faktu, że wskazuje on na konkretny element, tj.głos, dzięki któremu owce rozpoznają swojego Pasterza. Tym szczególnym głosem jest słowo Boże. Czerpiąc wciąż z proroctwa Ez 34, 13, Augustyn przyrównuje autorów biblijnych do „gór Izraela”, na których Bóg obiecuje paść swoje owce: „Autorzy Ksiąg świętych nazwani są „górami Izraela". Jeśli chcecie paść bezpiecznie, tam wypasajcie. Wszystko, co tam usłyszycie, kosztujcie z rozkoszą, wszystko zaś, co pochodzi z zewnątrz, odrzucajcie. Gromadźcie się wokół wzgórz Pisma Świętego. Tam odnajdziecie rozkosz waszego serca, tam nie ma nic zatrutego, nic szkodliwego, tam najobfitsze pastwisko"52.

Niezrównany autorytet natchnionych autorów nie jest jednak absolutny. Augustyn wyjaśnia dalej, że wprawdzie "góry” są miejscem odpoczynku i wzmocnienia, ale Tym, który pasie jest Pan. To On przynosi prawdziwą pomoc i to Jego głos ma być słyszalny w świętych księgach. Relatywizacja autorytetu autorów biblijnych ma na celu ukazanie konieczności właściwej interpretacji ksiąg świętych. Chrystologiczne kryterium hermeneutyczne przechodzi w sposób naturalny w kryterium eklezjologiczne. Głos jedynego Pasterza ma być słyszany na całym świecie, pozostając wciąż tym samym głosem. „Niech więc wszyscy będą w jednym Pasterzu, niech przemawiają jednym głosem Pasterza.

\footnotetext{
${ }^{49}$ Sermo 46, 30, 671-673, [w:] Liturgia godzin..., dz. cyt., t. 4, s. 235.

${ }^{50}$ Sermo 46, 30, 669-670, [w:] Liturgia godzin..., dz. cyt., t. 4, s. 235.

${ }^{51}$ Augustyn przywołuje go w kazaniu czterokrotnie - por. Sermo 46, 23, 547-548; 29, 647-648; 30, 684-685; 32, 724.

${ }^{52}$ Sermo 46, 24, 554-559, [w:] Liturgia godzin..., dz. cyt., t. 4, s. 230-231.
} 
Niech owce słuchają tego głosu i idą za swym Pasterzem. Nie za tym albo tamtym, ale za Jednym. Wszyscy zaś niech przemawiają w Nim jednym głosem, a nie różnymi głosami. „Upominam was, bracia, abyście byli zgodni i by nie było wśród was rozłamów" (1 Kor 10, 10). Niech owce słuchają tego głosu, który nie wprowadza żadnego rozłamu i podziału i niech idą za swym Pasterzem, który mówi: „Moje owce słuchają mego głosu i idą za Mną" (J 10, 27)"

Głos jedynego Pasterza nie może być zatem słyszany w schizmatyckiej grupie donatystów, bo ich interpretacje nie są przyjmowane we wspólnotach kościelnych całego świata. Katolickość Kościoła jest zapowiedziana i potwierdzona przez Pismo Święte, a ono z kolei znajduje właściwą interpretację jedynie w łonie powszechnego Kościoła. W ten sposób Chrystus, Kościół i Pismo Święte stanowią jedną rzeczywistość, której sługą staje się kapłan dla dobra ludu Bożego.

\section{Zakończenie}

Setki lat dzielą nas od św. Augustyna i setki kilometrów Polskę od Hippony (aktualnie Annaba w Algierii, blisko granicy z Tunezją). Pomimo tego dystansu czasowo-geograficznego, do którego można dodać jeszcze ten językowo-kulturowy, Kazanie o pasterzach stanowi doskonałą pomoc do odprawienia (lub poprowadzenia) rekolekcji kapłańskich. Biskup Hippony przedstawia wyjątkowo trafną diagnozę stanu Kościoła, i na jej podstawie przeprowadza duszpasterzom solidny rachunek sumienia. Precyzyjnie wskazuje na pułapki i niebezpieczeństwa czyhające na prezbiterów szukających nie służby, lecz kariery, nie ofiary, lecz zysku. Zdecydowanie piętnuje ich negatywne postawy: egoizm i szukanie własnych korzyści, pychę i pogoń za zaszczytami, lęk przed krytyką i odrzuceniem, a przede wszystkim zaniedbywanie ludu Bożego. Surowa ocena stanowi swoistą terapię, która ma pomóc w pokonaniu choroby trawiącej Ciało Chrystusa. Krytyka Augustyna, który nieustannie odwołuje się do Pisma Świętego, nie ma bowiem charakteru destrukcyjnego, ale stara się ukazać zbawczą perspektywę. Źli pasterze, a nawet ci, którzy odeszli od jedności Kościoła, mogą się stać znów dobrymi, jeżeli powrócą i zaczną naśladować jedynego

${ }^{53}$ Sermo 46, 30, 678-685, [w:] Liturgia godzin..., dz. cyt., t. 4, s. 236. 
Pasterza. „Bóg jako najwyższy Pasterz i prawdziwy Ogrodnik potrafi sprowadzić owce z powrotem i wszczepić na nowo [odcięte] gałązki" ${ }^{54}$.

Kapłan i biskup, którym powierzone są specjalna misja i urząd w Kościele, w pierwszym rzędzie są jednak chrześcijanami, a więc uczniami Chrystusa. Podkreślając prawdę o podstawowej równości wszystkich członków eklezjalnej wspólnoty, Augustyn podcina korzenie wszelkich tendencji klerykalnej wyniosłości. „Z wami jestem chrześcijaninem, dla was - biskupem"55 - powtarzał często, przypominając o zbawiennych owocach pokory, którą sam praktykował w stopniu heroicznym ${ }^{56}$.Jeżeli prezbiter ma wyprzedzać innych ludzi, to tylko w ofiarnej służbie, w gorliwym zgłębianiu i głoszeniu słowa Bożego, w uświęcaniu przez sakramenty, w miłosnym oddaniu Chrystusowi w Kościele. Powołanie do tej wyjątkowej misji jest szczególnym darem jedynego Pasterza, który poprzez ziemskich pasterzy chce nieustannie ukazywać swoją miłość i troszczyć się o swoje owce na całym świecie aż do skończenia świata. Duchowy pożytek owiec stanowi najgłębszy sens posługi kapłana, w którym powinny rozpoznać oblicze Dobrego Pasterza. Kapłan zaś ma świadomość, że prowadzi dzieło należące do Innego, że posługuje rzeczywistości, która przekracza jego ludzkie siły, że poświęca doczesne życie dla życia wiecznego.

Warszawa-Ołatarzewo

MIROSEAW MEJZNER SAC

Słowa kluczowe

Augustyn, pasterz, owce, słowo Boże, lud Boży, donatyzm

\section{Summary}

Good Shepherd and the shepherds of the Church in Sermo 46 of St. Augustine

Sermo 46 of St. Augustine's, offered for meditation in the 24th and 25th week of the Liturgy of the Hours, is entitled De pastoribus. The scriptural basis is constituted by the reading of Ez $34: 1-16$ where the prophet criticizes the shepherds of Israel who feed themselves and not their sheep, and announced the Lord's promise to feed his people

\footnotetext{
${ }^{54}$ Sermo 46, 18, 405-406, [w:] Liturgia godzin..., dz. cyt., t. 4, s. 225.

${ }^{55}$ Por. Sermo 46, 2; 47, 2; 340, 1.

${ }^{56}$ Por. F. Van der Meer, S. Agostino pastore d'anime, dz. cyt., s. 20.
} 
himself. Augustine, by using an actualizing, allegorical exegesis, develops his homily to describe a true Christian shepherd distinct from a mercenary. The latter only searches for his own interest and honour, symbolized by the sheep's milk and wool. His selfish attitude causes damage: the strong sheep become weak, then sick and in the end are lost. For Augustine the scattering of the sheep signifies approaching heretic and schismatic groups. The bishop of Hippo disputes especially with the donatists. He emphasizes that Christ is the foundation of our salvation, the only Good Shepherd whose sheepfold is the Catholic Church throughout the world. The shepherds are good when they belong to that sheepfold, and following Christ they accomplish their mission to feed the sheep. The meaning of priesthood is indeed to serve God's people by proclaiming the Word, distributing the Sacraments and promoting unity. The priest accomplishes Christ's work and not his own. Therefore his responsibility is immense, since it deals with the eternal life to which God will welcome all those who faithfully served him.

\section{Keywords}

Augustin, shepherd, sheep, God's word, God's people, donatismus 